\title{
MOLECULAR DETECTION OF ANTIBIOTIC RESISTANCE GENES IN MULTIDRUG-RESISTANT STAPHYLOCOCCUS AUREUS ISOLATES FROM DOG DENTAL PLAQUE
}

\author{
S. NOURI GHARAJALAR ${ }^{1} \&$ M. ONSORI ${ }^{2}$ \\ ${ }^{1}$ Department of Pathobiology, Faculty of Veterinary Medicine, University of Tabriz, \\ Tabriz, Iran; ${ }^{2}$ Private Veterinary Practitioner, Urmia, Iran
}

\begin{abstract}
Summary
Nouri Gharajalar, S. \& M. Onsori, 2019. Molecular detection of antibiotic resistance genes in multidrug-resistant Staphylococcus aureus isolates from dog dental plaque. Bulg. J. Vet. Med., 22, No 4, 419-427.

Multidrug resistant Staphylococcus aureus strains are a major health care problem both in humans and animals. In this work we described three multiplex PCR assays for detection of clinically relevant antibiotic resistance genes in $S$. aureus isolated from dog dental plaques. Thirty dental plaque samples were collected; then cultural, biochemical and molecular tests performed for isolation and identification of $S$. aureus from samples. The antibiotic susceptibility of the isolates were checked by Kirby Bauer disc diffusion method and the prevalence of antibiotic resistance genes determined using multiplex PCR assay. As a result $S$. aureus was isolated from 18 dog plaque samples. Fifteen of these isolates were resistant to penicillin. The mecA gene was more prevalent than blaZ among penicillinresistant bacteria. Ten of the isolates were resistant to tetracycline. The percentage of tet $M$ was higher than tet $K$ among them. Also, 10 of the isolates were resistant to cefazolin among them bla TEM detected in higher rate than $b l a_{S H V}$ and $b l a_{O X A-I}$. Hence multiplex PCR assay is a suitable method for detection of antibiotic resistance patterns of $S$. aureus isolates.
\end{abstract}

Key words: antibiotic resistance, Staphylococcus aureus, dental plaque, dog

\section{INTRODUCTION}

Dental plaque is the biofilm on the teeth with different types of microbes. It is an important agent of dental caries (Altayyar et al., 2015). Oral disorders are prevalent in dogs, causing pain and usually leading to tooth loss (Elliott et al., 2005). Dental caries results from bacterial decay of tooth structures. Oral bacteria which accumulate in dental plaque, ferment carbohydrates, and as a result, release acids on the tooth surface (Hale, 2009).

Periodontal disease is an important disorder of the oral cavity in dogs. Soft diet which is very popular among dog owners and the lack of hygiene causes accumulation of dental plaque colonised with bacteria (Kyllar \& Witter, 2005). 
Molecular detection of antibiotic resistance genes in multidrug-resistant Staphylococcus aureus ...

Periodontal disease occurs in two steps. Gingivitis is the first stage in which gum inflammation is induced by dental plaque bacteria. Periodontitis (inflammatory disease of the periodontal ligament and alveolar bone) is the second stage caused by mixed-species bacterial biofilm. These disorders are not only detrimental to the oral cavity but also affect the general health of the animal (Zambori et al., 2012).

From human dental plaques, Gram positive bacteria are isolated more frequently than Gram negative ones (Rozkiewicz et al., 2006). The bacterial composition of canine plaque was shown to be widely different from that of humans with only $16.4 \%$ of taxa shared. So, alternative mechanisms may play an important role during canine oral biofilm development. For example in humans, bacteria of the genus Streptococcus are necessary for initiate biofilm formation and the transition from health to disease is detected by a change from predominance of Gram positive species to mainly Gram negative ones. This situation is however reversed in canine plaque (with health associated species mainly belonging to the Gram negative group). On the other hand streptococcal species don't play an important role in canine plaque biofilms initiation and their prevalence is low. In one study, the most prevalent species among canine oral microbiome were Bergeyella zoohelcum, Neisseria shayeganii and Moraxella spp. (Holcombe et al., 2014).

$S$. aureus is an opportunistic pathogen colonising the teeth of patients, in the form of biofilm (Ansari et al., 2011). Antibiotic usage for treatment of periodontal disease or other oral infections may result in the increase of the number of staphylococci in the oral cavity. These bacteria easily become resistant to antibacterial drugs and this may lead to super infection (Loberto et al., 2004). Multidrug-resistant $S$. aureus constitute an important health care problem, so using suitable and specific tools the exact detection of antimicrobial resistance in these bacteria has become a significant concern in clinical diagnosis (Perez-Roth et al., 2001).

There are several phenotypic methods for detection of microorganisms' antimicrobial susceptibility patterns, which however are not discriminating enough. So, it is essential to use more rapid and accurate methods like PCR for identification of staphylococci and their resistance patterns (Pournajaf et al., 2014).

In this study, a Multiplex PCR assay was used to find out the prevalence of antibiotic resistance genes among different $S$. aureus strains isolated from dog dental plaque.

\section{MATERIALS AND METHODS}

\section{Sample collection}

Thirty dental plaque samples were collected from dogs undergoing routine dental treatment at Dr Onsori Pet Clinic, Urmia, Iran in 2016. A small scraping from the dental plaque was taken using a sterile curette. Each sample was immediately placed in phosphate-buffered saline and processed within 2-3 h from collection (Elliott et al., 2005).

\section{Isolation and identification of Staphylococcus spp.}

After homogenising the samples, they were inoculated on blood agar and manitol salt agar (Sigma, USA) for Staphylococcus isolation. The plates were incubated at $37{ }^{\circ} \mathrm{C}$ for $24 \mathrm{~h}$ (Devapria et al., 
2013). Gram staining, catalase and nitrate tests were also used as biochemical examinations to confirm Staphylococcus genus (Zambori et al., 2012).

\section{Molecular identification of S. aureus}

Total genomic DNA from all isolates suspected as Staphylococcus was extracted from overnight cultures at $37{ }^{\circ} \mathrm{C}$ in nutrient broth using DNA extraction kit (Fermentase, Germany). DNA concentrations were determined using spectrophotometer and the samples were stored at $-20{ }^{\circ} \mathrm{C}$ until used for PCR assay. The standard single PCR assay using a DNA thermo cycler (MWG AC BIOTECH THERMALCYCLER, USA), targeting $S$. aureus specific sequence was developed. Primers used in this study were: sau1: $5^{\prime}$ AAT CTT TGT CGG TAC ACG ATA TTC TTC ACG 3' and sau2: 5 CGT AAT GAG ATT TCA GTA GTA AAT ACA ACA3'. PCR amplification was performed in a $25 \mu \mathrm{L}$ reaction mixture consisted of $10 \mu \mathrm{L}$ Red Amp master mix $2 \times, 3 \mu \mathrm{L}$ of template DNA, $10 \mu \mathrm{L}$ of deionized water and $1 \mu \mathrm{L}$ of each primer. Reaction conditions were optimized to be $94{ }^{\circ} \mathrm{C}$ for $30 \mathrm{~min}$ as initial denaturation, followed by 30 cycles of $94{ }^{\circ} \mathrm{C}$ for $30 \mathrm{~s}, 55^{\circ} \mathrm{C}$ for $30 \mathrm{~s}$ and 72 ${ }^{\circ} \mathrm{C}$ for $30 \mathrm{~s}$ and a final extension step at $72{ }^{\circ} \mathrm{C}$ for $4 \mathrm{~min}$. Amplification products were electrophoresed in $1.5 \%$ agarose gel containing $1 \times \mathrm{TBE}$ at $75 \mathrm{~V}$ for $1.5 \mathrm{~h}$ and visualised under UV light. Amplification of $107 \mathrm{bp}$ band indicated S. aureus (Strommenger et al., 2003).

\section{Antibiotic susceptibility test}

Antimicrobial susceptibility testing was performed for bacterial isolates using Kirby-Bauer disk diffusion method on Mueller Hinton agar plates. Test cultures were swabbed on the top of the media and allowed to dry for $10 \mathrm{~min}$. The antimicrobial agents tested were: tetracycline $(30 \mu \mathrm{g})$, chloramphenicol $(30 \mu \mathrm{g})$, erythromycin $(15 \mu \mathrm{g})$, gentamicin $(10$ $\mu \mathrm{g})$, penicillin (10 units), vancomycin $(30 \mu \mathrm{g})$, azithromycin $(10 \mu \mathrm{g})$ and cefazolin $(30 \mu \mathrm{g})$. The zone of inhibition diameters $(\mathrm{mm})$ around the disks were measured and interpreted by referring to the performance standard for antimicrobial susceptibility testing, as described by the Clinical and Laboratory Standards Institute (CLSI) guidelines (2015).

Multiplex PCR for the detection of antibiotic resistance genes

Three multiplex PCR assays were performed to identify antibiotic resistance determinants. In the first assay for beta lactamase (penicillin) resistance genes $m e c A$ and blaZ were targeted. The mec $A$ and blaZ specific primer pairs for amplification of 532 and $700 \mathrm{bp}$ fragments were: $m e c A$ : F5' AAA ATC GAT GGT AAA GGT TGG C3' and R5' AGT TCT GCA GTA CCG GAT TTG C3', blaZ: F5' TGA CCA CTT TTA TCA GCA ACC3' and R5' GCC ATT TCA ACA CCT TCT TTC3'. Thermal profile initiated with $95{ }^{\circ} \mathrm{C}$ for $240 \mathrm{~s}$ (initial denaturation), followed by 30 cycles of $95{ }^{\circ} \mathrm{C}$ for $60 \mathrm{~s}$ (denaturation), $58{ }^{\circ} \mathrm{C}$ for $60 \mathrm{~s}$ (annealing) and $72{ }^{\circ} \mathrm{C}$ for $60 \mathrm{~s}$ (extension). The final extension step was at $72{ }^{\circ} \mathrm{C}$ for $420 \mathrm{~s}$. The PCR products were electrophoresed on $2 \%$ agarose gel for $1.5 \mathrm{~h}$ at $75 \mathrm{~V}$ and visualised under UV light (Kang et al., 2014).

For tetracyclines (tetracycline), tetM and tet $K$ genes fragments were targeted. The following primers were used: tet $K$ : F5' GTA GCG ACA ATA GGT AAT AGT 3' and R5' GTA GTG ACA ATA AAC CTC CTA3', tetM: F 5' AGT GGA GCG ATT ACA GAA3' and R 5' CAT 
Molecular detection of antibiotic resistance genes in multidrug-resistant Staphylococcus aureus ...

ATG TCC TGG CGT GTC TA3'. Initial denaturation which occurred at $94{ }^{\circ} \mathrm{C}$ for $3 \mathrm{~min}$, was followed by 30 cycles of amplification using the following parameters: $94{ }^{\circ} \mathrm{C}$ for $30 \mathrm{~s}$, annealing at $55^{\circ} \mathrm{C}$ for $30 \mathrm{~s}$, extension at $72{ }^{\circ} \mathrm{C}$ for $30 \mathrm{~s}$ and a final extension step at $72{ }^{\circ} \mathrm{C}$ for $4 \mathrm{~min}$. The PCR products were analysed by electrophoresis on a $1.5 \%$ agarose gel. Detection of the $158 \mathrm{bp}$ fragment of the $S$. aureus tet $M$ and a $360 \mathrm{bp}$ amplicon of tetk gene, was taken as indicative of the presence of the tet $M$ and tet $K$ genes, respectively (Strommenger et al., 2003).

Also bla $a_{T E M}, b_{\text {S }} a_{S H}$ and bla $a_{O X A-1}$ genes fragments were targeted for cephalosporins (cefazolin). The bla $a_{T E M}$, bla $a_{S H V}$ and bla $a_{O X A-1}$ specific primer pairs used for amplification of 516, 392 and $619 \mathrm{bp}$ fragments were as followed: bla $a_{T E M}$ : F5'ATC AGC AAT AAA CCA GC3' and R5' CCC CGA AGA ACG TTT

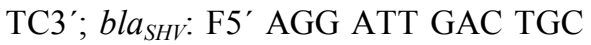
CTT TTTG 3' and R5' CGC TCG 3'; bla $_{O X A-1}:$ F5' ATA TCT CTA CTG TTG CAT CTC C3' and R5' AAA CCC TTC AAA CCA TCC3'.

The thermal cycling protocol for PCR comprised $94{ }^{\circ} \mathrm{C}$ for $5 \mathrm{~min}$, followed by 32 cycles of $94{ }^{\circ} \mathrm{C}$ for $30 \mathrm{~s}, 54{ }^{\circ} \mathrm{C}$ for $30 \mathrm{~s}$ and $72{ }^{\circ} \mathrm{C}$ for $1 \mathrm{~min}$. Final step was at $72{ }^{\circ} \mathrm{C}$ for $10 \mathrm{~min}$. The PCR products were analysed by electrophoresis on $2 \%$ agarose gel (Colom et al., 2003).

\section{RESULTS}

Out of 30 collected plaque samples, 18 were suspected as staphylococci based on colony morphology and Gram staining (Gram positive cocci). All these isolates were catalase and nitrate positive. They had $\beta$-haemolytic colonies on blood agar plates and yellow coloured colonies on mannitol salt agar.
The PCR confirmed all 18 isolates as S. aureus as an amplified product of 107 bp band was observed in each case without amplification in negative control (Fig. 1).

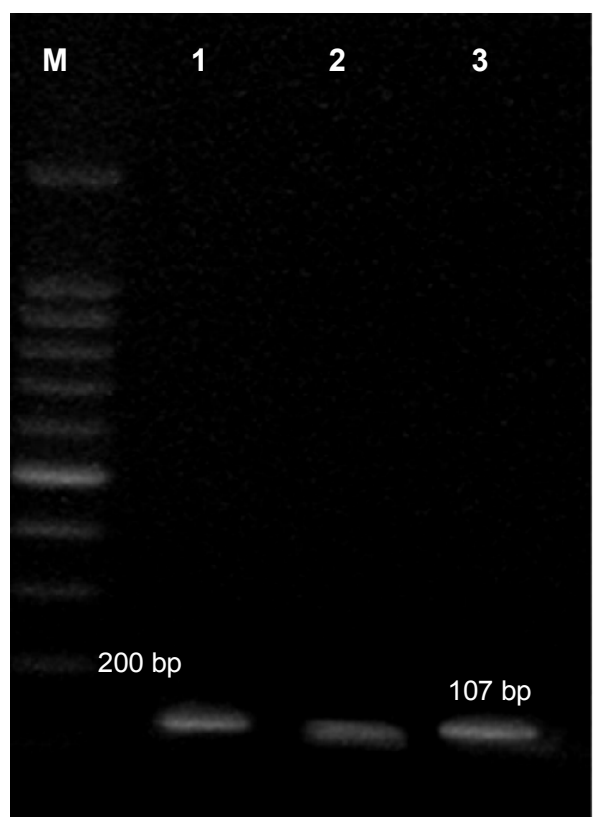

Fig. 1. Gel electrophoresis of the PCR products of $S$. aureus specific sequence. Lane M: $100 \mathrm{bp}$ ladder marker; lane 1: positive control; lanes 2, 3: $S$. aureus specific sequence at $107 \mathrm{bp}$.

The results of antimicrobial sensitivity testing of the $18 \mathrm{~S}$. aureus isolates using the disc diffusion method showed that 12 isolates had phenotypic resistance to at least two antimicrobial drugs (Table 1). With this method 15 of the isolates showed resistance to penicillin, 10 were resistant to tetracycline and 10 were resistant to cefazolin. Eight strains were resistant to vancomycin, 8 to erythromycin, 7 to azithromycin and chloramphenicol; only 6 of the isolates were resistant to gentamicin. 
Table 1. Number of multiple resistance patterns in S. aureus isolates

\begin{tabular}{|c|c|c|}
\hline $\begin{array}{l}\text { Pattern } \\
\text { No. }\end{array}$ & Antimicrobial resistance against: & $\begin{array}{c}\text { Number of resistant } \\
\text { S. aureus isolates }\end{array}$ \\
\hline 1 & $\begin{array}{l}\text { cefazolin, gentamicin, vancomycin, azithromycin, } \\
\text { tetracycline, chloramphenicol, erythromycin, penicillin }\end{array}$ & 4 \\
\hline 2 & $\begin{array}{l}\text { cefazolin, vancomycin, azithromycin, tetracycline, } \\
\text { chloramphenicol, erythromycin, penicillin }\end{array}$ & 1 \\
\hline 3 & cefazolin, tetracycline, erythromycin, penicillin, & 2 \\
\hline 4 & cefazolin, erythromycin, penicillin & 1 \\
\hline 5 & $\begin{array}{l}\text { chloramphenicol, azithromycin, tetracycline, } \\
\text { chloramphenicol, E, penicillin }\end{array}$ & 1 \\
\hline 6 & cefazolin, tetracycline, penicillin & 1 \\
\hline 7 & $\begin{array}{l}\text { cefazolin, tetracycline, chloramphenicol, } \\
\text { erythromycin, penicillin }\end{array}$ & 1 \\
\hline 8 & penicillin, azithromycin & 1 \\
\hline
\end{tabular}

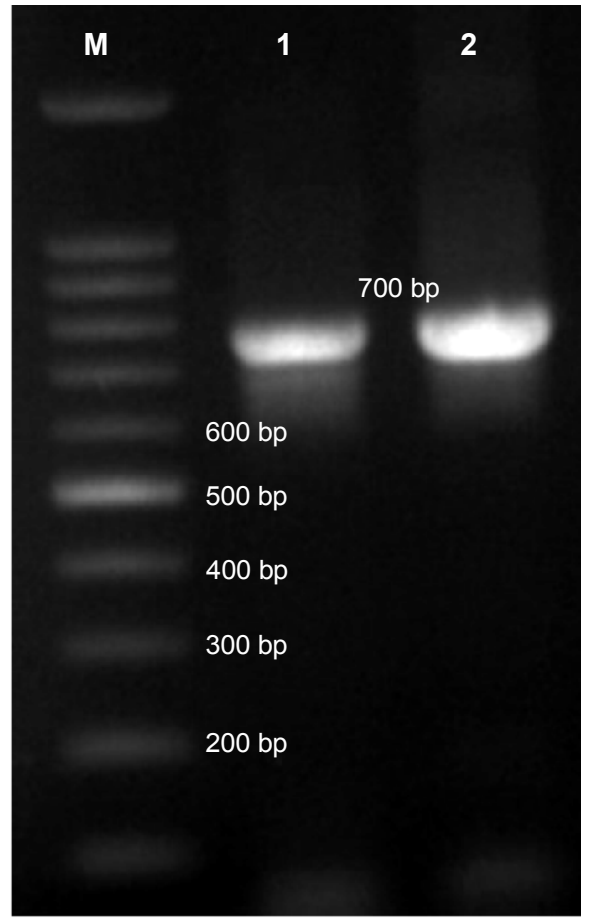

Fig. 2. PCR identification of blaZ with 700 bp on $2 \%$ agarose gel. Lane M: 100 bp ladder marker; lane 1: positive control; lane 2: blaZ gene at $700 \mathrm{bp}$.
The PCR based detection of different antimicrobial resistance determinants showed that 7 of penicillin-resistant isolates had the blaZ and 18 had the mecA gene (Fig. 2, 3).

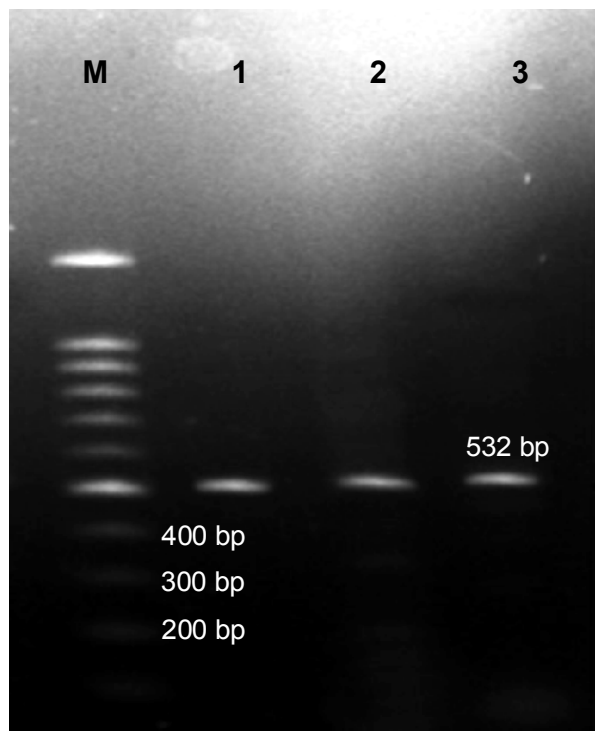

Fig. 3. $m e c A$ genes at 532 bp on agarose gel after PCR amplification. Lane M: $100 \mathrm{bp}$ ladder marker; lane 1: negative control; lane 2: positive control; lanes 3: mecA gene at $532 \mathrm{bp}$. 
Molecular detection of antibiotic resistance genes in multidrug-resistant Staphylococcus aureus ...

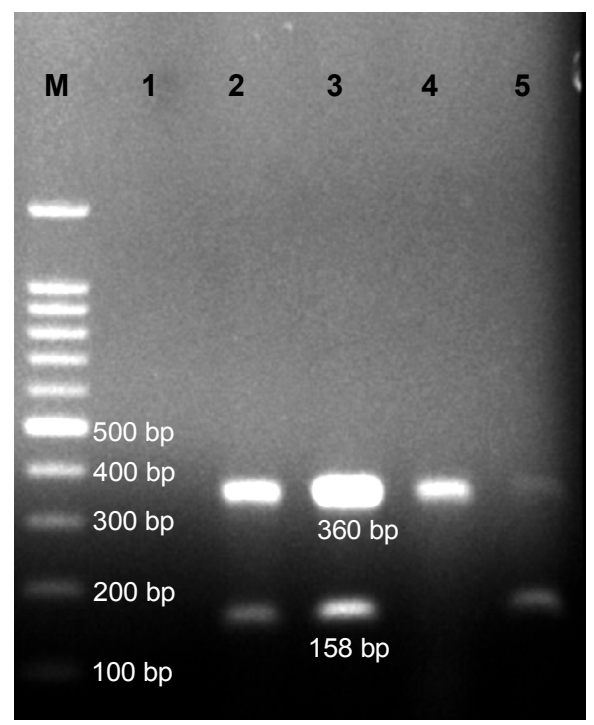

Fig. 4. Gel electrophoresis for PCR product of tet $K$ and tet $M$ markers in $S$. aureus isolates. Lane M: 100 bp ladder marker; lane 1: negative control; lane 2: positive control; lanes 3,5: tet $K$ gene at $360 \mathrm{bp}$ and tet $M$ gene at $158 \mathrm{bp}$; lane 4: tet $K$ gene at $360 \mathrm{bp}$.

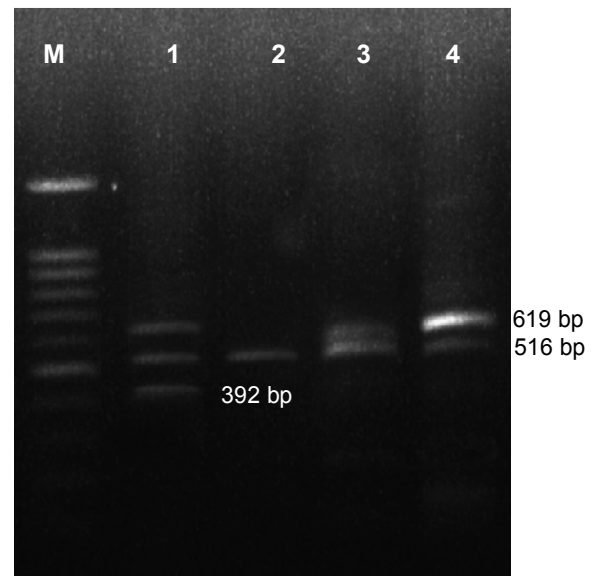

Fig. 5. bla $_{T E M}, b l a_{S H V}$ and $b l a_{O X A-1}$ genes at 392, 516 and 619 bp on agarose gel after PCR amplification. Lane M: 100 bp ladder marker; lane 1: 2 bla $_{T E M}$ and bla OXA-I $_{\text {genes at }}$ 516 and $619 \mathrm{bp}$; lane 3: bla TEM $_{\text {gene }}$ at 516 bp; lane 4: bla $_{T E M}, b_{\text {SI }}$ and bla $_{O X A-1}$ genes at 516, 392 and $619 \mathrm{bp}$.

\section{DISCUSSION}

Biofilm is a microbial community in which cells are attached to a substratum or to each other and are embedded in a matrix of extracellular polymeric materials (Zambori et al., 2012). Dental biofilm (plaque) is an important factor in development of dental caries (Altayyar et al., 2015). In the oral cavity teeth have enough humidity and adherent surfaces for formation of dental plaque. Aerobic bacteria like Staphylococci are usually isolated from the oral cavity (Zambori et al., 2012).

Zambori et al. (2015) tested the biofilm formation capacity of planktonic bacterial strains. They used microbiological examination and concluded that from all 75 isolated bacterial strains 10 were from the Staphylococcus genus $(30.3 \%)$. In our study the percentage of Staphylococcus genus in dog dental plaque samples was higher $(60 \%)$.

Altayyar et al. (2015) isolated and identified aerobic bacteria from human dental plaque biofilms using conventional methods, and revealed that $21 \%$ of the isolates were Staphylococcus. In this study we isolated 18 Staphylococcus strains from 30 clinical samples which indicates the more important role of $S$. aureus in canine dental plaque formation than in human one.

The prevalence of Streptococcus mutans and Streptococcus sobrinus in canine dental plaque was previously studied (Nouri Gharajalar \& Hassanzade, 2017). These bacteria were isolated from $40 \%$ and $10 \%$ of tested samples, respectively. Also most of them showed multidrug resistance patterns toward eight tested antibiotics. In comparison with this study, it seems that Staphylococcus genus was more frequent than Str. mutans in canine dental biofilms. Both were resis- 
tant to the most tested antibiotics. The molecular characteristics of multidrug resistant Lactobacillus isolated from canine dental biofilms were investigated in a previous study of ours. According to the results, the prevalence of these bacteria was $56.6 \%$ which was almost equal to the frequency of Staphylococcus in this study. Additionally, the presence of multidrug resistance patterns among tested Lactobacillus was in line with the present study on Staphylococcus (Nouri Gharajalar, 2017).

To improve the diagnosis of $S$. aureus and its potential antibiotic resistance in dog dental plaques, a single PCR assay was developed. All phenotypically identified isolates were also confirmed by PCR method. Also, three multiplex PCR assays were used for detection of penicillin, cefazolin and tetracycline resistance genes.

The relation between the phenotypic antibiotic susceptibility patterns and the antibiotic resistance genes among methicillin resistant $S$. aureus isolates was evaluated (Adwan et al., 2014). It was concluded that multiplex PCR can be used for confirmation of the results obtained by the disc diffusion test, in accordance with our findings.

Trzcinski et al. (2000) studied the expression of resistance to tetracyclines in methicillin resistant $S$. aureus strains. They reported that the tet $K$ genotype was detected in Polish isolates heterogeneously resistant to methicillin but the tetM genotype was observed in isolates homogeneously resistant to methicillin. In the present experiment, we also identified the prevalence of tet $K$ and tet $M$ genes in tetracycline-resistant $S$. aureus isolates and concluded that the tet $M$ gene was more prevalent than tet $K$ among our isolates.
A PCR assay for detection of nine antibiotic resistance genes of $S$. aureus was described. Among 30 Staphylococcus isolates, 10 were resistant to oxytetracycline. They carried either tetK or tet $M$ resistance genes (Strommenger et al., 2003).

PCR based identification of methicillin resistant $S$. aureus strains and their antibiotic resistance patterns were evaluated by Pournajaf et al. (2014). Among antibiotics used in their study, penicillin showed the least activity against $S$. aureus and vancomycin was the most effective. In the PCR assay, $45 \%$ of the isolates had the mecA gene. Also, Asfour et al. (2011) detected both mecA and blaZ genes in Staphylococcus strains isolated from bovine mastitis. They reported that $80 \%$ of the beta-lactam resistant staphylococci had the mecA gene and $68 \%$ had a blaZ determinant. In our study $m e c A$ gene was also more common than blaZ among $S$. aureus isolates.

For determining cefazolin resistance genes, three bla TEM $_{\text {, bla }} a_{S H V}$ and bla $a_{O X A-1}$ genes were targeted by PCR assay. As a result the most prevalent genotype was for $b l a_{T E M}$ gene followed by bla $a_{O X A-1}$ and $b l a_{S H V}$ genes. In the study of Colom et al. (2003), a simple and reliable PCR assay was used for detection of bla $a_{T E M}, b l a_{S H V}$ and bla ${ }_{O X A-1}$ genes. Their results was similar to ours.

In conclusion, this study demonstrated that $S$. aureus strains are amongst the most prevalent bacteria isolated from dog dental plaques. It was also observed that $66.6 \%$ of these bacteria had multidrug resistant patterns to tested antibiotics especially to cefazolin, tetracycline, and penicillin which were mainly caused by bla TEM, tetM, and mecA genes. 
Molecular detection of antibiotic resistance genes in multidrug-resistant Staphylococcus aureus ...

\section{REFERENCES}

Adwan, G., K. Adwan, N. Jarrar \& A. Amleh, 2014. Molecular detection of nine antibiotic resistance genes in methicillin resistant Staphylococcus aureus isolates. Romanian Archives of Microbiology and Immunology, 73, 9-18.

Altayyar, I. A., M. A. Abdalla, M. A. A. Alfellani \& O. O. Abdullah, 2015. Determination of aerobic bacterial composition of dental plaque biofilms and their role in oral health. Emergent Life Sciences Research, 1, 8-12.

Ansari, S. H. A., R. Baqai, M. R. Memon, M. Aziz \& M. K. H. Khan, 2011. Biofilm formation and isolation of Staphylococcus aureus from blood cultures of dental patients undergoing oral surgical producers. Journal of the Pakistan Dental Association, 20, 154-158.

Asfour, H. A. E. \& S. F. Darwish, 2011. Phenotypic and genotypic detection of both $m e c A$ and blaZ genes mediated beta-lactam resistance in Staphylococcus strains isolated from bovine mastitis. Global Veterinaria, 6, 39-50.

Colom, K., J. Perez, R. Alonson, A. Fernandez-Aranguiz, E. Larino \& R. Cisterna, 2003. Simple and reliable multiplex PCR assay for detection of blaTEM, bla SHV and bla OXA-1 genes in Enterobacteriaceae. FEMS Microbiology Letters, 223, 147-151.

Devapria, F., R. Ramesh, A. K. Sajit Khan \& J. Shanmugan, 2013. B-lactamase production of Staphylococcus aureus: A comparison study of different iodometric methods. Gulf Medical Journal, 2, 16-21.

Elliott, D. R., M. Wilson, C. M. F. Buckley \& D. A. Spratt, 2005. Cultivable oral microbiota of domestic dogs. Journal of Clinical Microbiology, 43, 5470-5476.

Hale, F. A., 2009. Dental caries in dog. $\mathrm{Ca}$ nadian Veterinary Journal, 50, 13011304.

Holcombe, L. J., N. Patel, A. Colyer, O. Deusch \& S. Harris, 2014. Early canine plaque biofilms: characterization of key bacterial interactions involved in initial colonization of enamel. PLoS One, 9, e113744.

Kang, M. H., M. J. Char, J. W. Yoon, S. G. Kim, S. Y. Lee, J. H. Yoo \& H. M. Park, 2014. Antibiotic resistance and molecular characterization of ophthalmic Staphylococcus pseudintermedius isolates from dogs. Journal of Veterinary Science, $\mathbf{1 5}$, 409-415.

Kyllar, M. \& K. Witter, 2005. Prevalence of dental disorders in pet dogs.Veterinarni Medicina, 50, 496-505.

Loberto, J. C., C. A. de Paiva Martins, S. S. Ferreira dos Santos, J. R. Cortelli \& A. O. C. Jorge, 2004. Staphylococcus spp. in the oral cavity and periodontal pockets of periodontitis patients. Brazilian Journal of Microbiology, 35, 64-68.

Nouri Gharajalar, S., 2017. Molecular characterization of multidrug resistant Lactobacillus isolated from dental plaque of dogs using Multiplex PCR assay. Bulgarian Journal of Veterinary Medicine. DOI: 10. $15547 /$ bjvm. 2000 .

Nouri Gharajalar, S. \& M. Hassanzade, 2017. Antibacterial properties of Carum copticum essential oil against mutans Streptococci isolated from dog dental plaque. Veterinarni Medicina, 62, 654-660.

Perez-Roth, E., F. Claverie-Martin, J. Villar \& S. Mendez-Alvarez, 2001. Multiplex PCR for simultaneous identification of Staphylococcus aureus and detection of methicillin and mupirocin resistance. Journal of Clinical Microbiology, 39, 4037-4041.

Performance Standards for Antimicrobial Susceptibility Testing, 2015. $25^{\text {nd }}$ Informational Supplement. CLSI document, Wayne, USA, 100-S25.

Pournajaf, A., A. Ardebili, L. Goudarzi, M. Khodabandeh, T. Narimani \& H. Abbaszadeh, 2014. PCR-based identification of methicillin-resistant Staphylococcus aureus strains and their antibiotic resistance 
profiles. Asian Pacific Journal of Tropical Biomedicine, 4, 293-297.

Rozkiewicz, D., T. Daniluk, M. L. Zaremba, D. Cylwik-Rokicka, E. Luczaj-Cepowicz, R. Milewska, G. Marczuk-Kolada \& W. Stokowska, 2006. Bacterial composition in the supragingival plaques of children with and without dental caries. Advances in Medical Sciences, 51, 182-186.

Strommenger, B., C. H. Kettlitz, G. Werner \& W. Witte, 2003. Multiplex PCR assay for simultaneous detection of nine clinically relevant antibiotic resistance genes in Staphylococcus aureus. Journal of Clinical Microbiology, 41, 4039-4094.

Trzcinski, K., B. S. Cooper, W. Hryniewicz \& C. H. G. Dowson, 2000. Expression of resistance to Tetracycline in strains of methicillin resistant Staphylococcus aureus. Journal of Antimicrobial Chemotherapy, 45, 763-770.
Zambori, C., E. Tirziu, I. Nichita, C. Cumpanasoiu, R. Valentin Gros, M. Seres, B. Mladin \& D. Mot, 2012. Biofilm implication in oral diseases of dogs and cats. Journal of Animal Science and Biotechnology, 45, 208-212.

Paper received 04.10.2017; accepted for publication 02.02.2018

\section{Correspondence:}

S. Nouri Gharajalar Department of Pathobiology, Faculty of Veterinary Medicine, University of Tabriz, Tabriz, Iran cell number: 00989141468635 e-mail: saharnouri@yahoo.com 